\title{
Pollen sources for Apis mellifera L (Hym, Apidae) in Surinam, based on pollen grain volume estimates
}

\author{
JC Biesmeijer 1, B van Marwijk 1, K van Deursen 1, \\ W Punt 2, MJ Sommeijer 1
}

\author{
1 Utrecht University, Laboratory of Comparative Physiology, PO Box 80086, 3508 TB Utrecht; \\ 2 Utrecht University, Laboratory of Palaeobotany and Palynology, \\ Heidelberglaan 2, 3584 SC Utrecht, The Netherlands
}

(Received 4 November 1991; accepted 19 March 1992)

\begin{abstract}
Summary - Every 3 or 4 days over a 1-year period, pollen samples were taken from Apis mellifera hives in Surinam in order to identify pollen sources, and to determine how these sources varied during the year. The second aim of this study was to compare the results of pollen counts with relative volume estimates. Each sample contained up to 15 pollen types. On the basis of relative volume estimates in combination with frequency, we found that the most important year-round pollen sources were Cecropia sp. Palmae type 1, Cocos nucifera, and Compositae type 1. Pollen types that were periodically important included Ceiba pentandra, Myrtaceae type 1, Abutilon type, Spondias mombin, and Terminalia sp. Up till now the importance of pollen sources has been measured directly by counting pollen grains. In this paper we show that such data do not reveal the actual importance of these sources for the bees. Data from the volume estimates show a much more diverse bee diet during the year as well as on a single day than that shown by the pollen counts.
\end{abstract}

pollen analysis / pollen grain volume / pollen plant / neotropics

\section{INTRODUCTION}

For honeybees pollen is the only source of protein and lipids (Stanley and Linskens, 1974). Like other eusocial bees, honeybees are polylectic, eg they use different plant species. Bees constantly have to make a choice between the available food sources. Their choice is determined by the abundance and the relative quality of the source, distance of the source from the hive, and by the previous experience of individual bees (Seeley, 1985; Seeley et al, 1991).

Food sources of bees can be studied indirectly by analysing the pollen and nectar collected by the bees. Information on flower-visiting by European and African honeybees in the neotropics is available only for São Paulo, Brazil (CortopassiLaurino and Ramalho, 1988; ImperatrizFonseca et al, 1989), Panama (Roubik et al, 1986), Trinidad (Sommeijer et al, 1983) and French Guiana (Roubik, 1979). Al- 
though Engel and Dingemans-Bakels (1980) identified the sources of pollen collected by stingless bees in Surinam, our study is the first to examine pollen collecting by honeybees in the Guianas.

In this paper we also investigate the importance of specific pollen sources. The importance of a source is determined by the quality and the quantity of the pollen. Little is known about the nutritive value of various tropical pollens, how bees extract the pollen contents, or whether they can break down pollen grains selectively (Stanley and Linskens, 1974; Kroon et al, 1974; Cruz-Landim, 1985). The importance of different plant species is normally determined by counting the pollen grains (see the review on neotropical honeybees and stingless bees; Ramalho et al, 1990). The diversity and the variation of source utilization throughout the year is normally demonstrated by calculating pollen niche size and evenness (Ramalho et al, 1985; Cortopassi-Laurino and Ramalho, 1988).

In determining the importance of the source directly from pollen grain counts, it is assumed that the quality and the volume of every single pollen grain are equal. As a result the conclusion is reached that abundant pollen types are more important for the bees than sporadically observed types.

The size of pollen grains, however, varies widely. The diameter of European pollens, for example, ranges approximately from 5 to $200 \mu \mathrm{m}$ (Stanley and Linskens, 1974). In a study of the relations between stingless bees and palms in Panama, Roubik and Moreno (1990) found that in 9 species of palms the length of the palm pollen grains ranged from 38 to $142 \mu \mathrm{m}$. They stated that as the palm pollen grains were relatively large in size, simple counts of grains did not reflect the relative representation in bee diets.

The present study was designed to: i) identify the important pollen sources used by African honeybees in Surinam; ii), investigate the diversity and the variation of pollen sources during the year; iii) compare the results of pollen counts with relative volume estimates.

\section{MATERIAL AND METHODS}

Pollen samples were taken from 2 Apis mellifera $L$ hives. One hive was sampled from 31 May 1986 to 8 January 1987, the other from 9 January to 31 May 1987. Sampling was performed using a pollen collecting trap. From 31 May to 20 August 1986 a 24 -h pollen harvest was collected every 3 or 4 days. From 20 August 1986 to 31 May 1987 the trap remained in place and pollen was collected twice a week.

Both colonies were located on the farm of $K$ van Deursen in the Bomapolder, SSE of Paramaribo, $55^{\circ} 5^{\prime} \mathrm{N} 5^{\circ} 45^{\prime} \mathrm{W}$ (Surinam, South America). The area around the farm consists of cultivated land (planted with Cocos nucifera, Psidium guajava, Carica papaya, Citrus spp) and on which is also found swamp and stretches of forest (containing Pterocarpus sp, Ceiba pentandra and Triplaris guianensis).

Samples were processed by a standard acetolysis method (Reitsma, 1969) and analysed at the Laboratory of Palaeobotany and Palynology of Utrecht University.

Pollen types were identified using the reference slide collection of the palynological institute. This collection was built up from earlier studies (Engel and Dingemans, 1980; Sommeijer et al, 1983; Bootsma et al, 1988). The relative representation of pollen types in each sample was estimated by random counting of 200 pollen grains (on 2 slides).

The volume of each pollen type was estimated by measuring dimensions, and calculated volume by mathematical formulae.

For some pollen grains which did not match geometric figures, volume was estimated as well as possible. Obtained volume was divided by that of pollen grains of Cecropia sp (the smallest pollen type found) which gives the relative volume used in this paper. The absolute volume cannot be given, because this approach can lead to size modifications (Reitsma, 1969). The relative volume, however, can be estimated adequately. 
To investigate the impact of the methodological differences on parameters derived from pollen counts and volume estimates, the pollen niche size and the evenness of source use were calculated. These parameters are regularly used to indicate the diversity of pollen sources and the utilization of these sources during the year.

The pollen niche size, $H^{\prime}$, is expressed by the Shannon-Weaver diversity index (1949):

$$
H^{\prime}=-\Sigma p_{\mathrm{h}} \cdot \ln (\mathrm{Ph})
$$

where $p_{\mathrm{h}}=$ proportion of pollen from plant species $h$ visited in the month in question.

The evenness index $J$ ' was calculated according to Pielou (1977)

$$
J^{\prime}=\frac{H^{\prime}}{H_{\text {max }}^{\prime}}
$$

where $H_{\text {max }}^{\prime}=$ natural logarithm of the total number of polien types present in the samples. $J^{\prime}$ therefore varies from 0 (heterogeneous utilization of sources) to 1 (homogeneous utilization of sources).

To compare the results of grain counts with the results of volume estimates, $H^{\prime}$ and $J^{\prime}$ were calculated using the results of both methods.

\section{RESULTS}

\section{Spectrum of pollen sources}

Ninety-two pollen samples were analysed; these were found to contain 52 different pollen types, 21 of which occurred in over $10 \%$ of the samples (table I). Six types could be identified at species level, 17 at genus level, and 21 at family level. Eight types remained unidentified. Twenty-nine families were represented in the samples. The number of pollen types per sample ranged from 1 to 15 , the average being 8.1. The pollen sources can be divided into 4 groups as shown below.

\section{Very important year-round pollen sources}

Cecropia sp, Palmae type 1, Cocos nucifera and Compositae type 1 were present in more than $75 \%$ of the samples, and made up the bulk of the volume and grains during the sampling period. On average, $62 \%$ of the volume and $84 \%$ of the total number of grains consisted of 2 species only: $\mathrm{Ce}$ cropia $\mathrm{sp}$ (average volume per sample $36 \% ; 68 \%$ of the grains counted) and $\mathrm{Pal}-$ mae $(26 \%$; $16 \%)$.

\section{Important year-round pollen sources}

Myrtaceae type 1, Spondias mombin, Graminae type 1 were present in approximately half the samples spread more or less equally over the year.

\section{Periodically important pollen sources}

Piperaceae type 1, Ceiba pentandra, Abutilon type, Onagraceae type 1, Terminalia sp, Tapirira guianensis, Malpighiaceae type were present in less than $30 \%$ of the samples, but were important pollen sources during short periods. A striking example in this group is Ceiba pentandra, which was found in $13 \%$ of the samples only from 2 March to 15 May during which time it made up more than $40 \%$ of the pollen volume.

\section{Minor pollen sources}

This group includes all other species present in less than $30 \%$ of the samples, many occurring only occasionally. Most of these species normally did not exceed the $5 \%$ level per sample. 
Table I. Comparison of important pollen sources.

Family

Rel vol $>10 \%$

genus/species

Acanthaceae

Hygrophila sp

Alismataceae

Echinodorus sp

Anacardiaceae

Spondias mombin

Tapirira guianensis

Araliaceae

spec

Bombacaceae

Ceiba pentandra

Boraginaceae

Cordia sp

type 1

Caesalpiniaceae

of Cassia type

Macrolobium

Caricaceae

Carica papaya

Chenopodiaceae

spec

Combretaceae

Terminalia $\mathrm{sp}$

Compositae

type 1

type 2

type 3

type 4

type 5

type 6

170

17

81

13

11

128

102

5

26

56

30

21

5

17

21

30

21

30

21

Cucurbitaceae

Momordica charantia 205

Euphorbiaceae

Amanoa type

Euphorbia type

Securinica type

Graminae

Zea mays

type 1

type 2

Labiatae

Hyptis type

Loranthaceae

spec

Malpighiaceae

type 1

Malvaceae

Abutilon type

21

140

17

686

16

90

21

6

21

91

\begin{tabular}{|c|c|c|c|c|c|c|}
\hline - & - & $F$ & $F$ & - & - & - \\
\hline- & - & - & - & - & - & - \\
\hline - & - & - & - & - & - & - \\
\hline- & - & - & - & - & - & - \\
\hline- & - & - & - & - & - & - \\
\hline $\mathrm{s}$ & - & - & - & G & - & - \\
\hline- & - & - & - & - & - & - \\
\hline- & $F$ & $F$ & $G$ & - & - & - \\
\hline- & - & - & - & - & - & - \\
\hline - & - & - & - & - & - & - \\
\hline- & - & - & - & - & - & - \\
\hline- & - & - & - & - & - & - \\
\hline- & G & $G$ & - & - & - & - \\
\hline- & - & - & - & - & - & - \\
\hline$F$ & $F$ & $F$ & - & - & $F$ & - \\
\hline - & - & - & - & - & - & - \\
\hline- & - & - & - & - & - & - \\
\hline- & - & - & - & - & - & - \\
\hline- & - & - & - & - & - & - \\
\hline$F$ & - & - & - & - & - & - \\
\hline - & - & - & - & - & - & - \\
\hline- & - & $F$ & - & - & - & - \\
\hline - & - & - & - & - & - & - \\
\hline$F$ & $F$ & $F$ & $F$ & $F$ & $F$ & $F$ \\
\hline - & - & - & - & - & - & - \\
\hline- & - & - & - & - & - & - \\
\hline- & - & - & - & - & - & - \\
\hline- & - & - & - & - & - & - \\
\hline- & - & - & - & - & - & - \\
\hline- & - & - & - & - & - & - \\
\hline - & - & - & - & - & - & - \\
\hline $\mathrm{S}$ & - & $S$ & $S$ & - & - & - \\
\hline$F$ & $F$ & - & - & $F$ & $F$ & $F$ \\
\hline- & - & - & - & - & - & - \\
\hline - & - & - & - & - & - & - \\
\hline - & - & - & - & - & - & - \\
\hline$F$ & $F$ & $F$ & - & - & - & $F$ \\
\hline$S$ & - & - & $S$ & - & - & - \\
\hline - & - & - & - & - & - & - \\
\hline - & - & - & - & - & $=$ & - \\
\hline- & - & - & - & - & $F$ & - \\
\hline- & $G$ & - & $G$ & - & - & - \\
\hline- & - & - & $F$ & - & - & - \\
\hline - & - & - & - & - & - & - \\
\hline- & - & $F$ & $F$ & $F$ & - & - \\
\hline- & - & - & - & - & - & - \\
\hline- & $F$ & $F$ & $F$ & - & - & - \\
\hline & - & - & - & - & - & \\
\hline
\end{tabular}




\begin{tabular}{|c|c|c|c|c|c|c|c|c|c|}
\hline Menispermaceae & & & - & - & - & - & $\mathrm{F}$ & - & - \\
\hline type 1 & 5 & & - & - & - & - & - & - & - \\
\hline Mimosaceae & & & $\mathrm{F}$ & $\mathrm{F}$ & $\mathrm{F}$ & $\mathrm{F}$ & $\mathbf{F}$ & $\mathrm{F}$ & $\mathrm{F}$ \\
\hline polyade type & 9 & & - & - & - & - & - & - & - \\
\hline Moraceae & & & - & - & - & - & $\mathbf{F}$ & - & $F$ \\
\hline Cecropia sp & 1 & * & G & - & $\mathrm{G}$ & - & G & G & G \\
\hline type 1 & 9 & & - & - & - & - & - & - & - \\
\hline Myrtaceae & & & $\mathrm{F}$ & - & $\mathrm{F}$ & $\mathrm{F}$ & $\mathrm{F}$ & $\mathrm{F}$ & $\mathrm{F}$ \\
\hline non Psidium type & 4 & * & - & - & - & - & - & - & - \\
\hline Onagraceae & & & - & $F$ & - & $F$ & $\mathrm{~F}$ & - & - \\
\hline type 1 & 40 & * & - & - & - & - & - & - & - \\
\hline Palmae & & & $\mathrm{F}$ & $\mathrm{F}$ & $\mathrm{F}$ & $\mathrm{F}$ & $\mathrm{F}$ & - & $\mathrm{F}$ \\
\hline Cocos nucifera & 73 & * & $\mathrm{s}$ & $\mathrm{S}$ & $S$ & $\mathrm{~S}$ & - & - & - \\
\hline type 1 & 21 & * & - & - & - & - & - & - & - \\
\hline Papilionaceae & & & - & $\mathrm{F}$ & $\mathrm{F}$ & $\mathrm{F}$ & $\mathrm{F}$ & - & $\mathrm{F}$ \\
\hline Pterocarpus type & 9 & & - & - & - & - & G & - & - \\
\hline Piperaceae & & & - & - & $\mathrm{F}$ & - & $\mathrm{F}$ & - & - \\
\hline type 1 & 2 & * & - & - & - & - & - & - & - \\
\hline Rubiaceae & & & $F$ & - & - & - & $F$ & - & - \\
\hline Borreria type & 114 & & - & G & - & $\mathrm{G}$ & - & - & - \\
\hline Rutaceae & & & - & - & - & - & - & - & - \\
\hline Citrus sp & 21 & & G & G & $\mathrm{G}$ & G & - & G & $\mathbf{G}$ \\
\hline Solanaceae & & & - & - & $\mathrm{F}$ & $\mathrm{F}$ & - & - & - \\
\hline Datura type & 281 & & $\mathrm{G}$ & - & - & - & - & - & - \\
\hline Species overlap & & & 4 & 1 & 2 & 3 & 0 & 0 & 0 \\
\hline Genus overlap & & & 3 & 4 & 3 & 4 & 3 & 2 & 2 \\
\hline Family overlap & & & 12 & 14 & 17 & 19 & 15 & 7 & 10 \\
\hline
\end{tabular}

Rel vol = relative volume obtained in this study. ${ }^{*}=$ pollen type present in more than $10 \%$ of the samples in this study. Other data after: 1 = Sommeijer et al (1983); $2=$ Roubik (1979); $3 \mathrm{M}=$ Engel and Dingemans-Bakels (1980), Meliponini; 3T = Engel and Dingemans-Bakels (1980), Trigonini; $4=$ Roubik et al (1986); $5=$ Imperatriz-Fonseca et al (1989); 6 = Cortopassi-Laurino and Ramalho (1988).

\section{Comparison of methods}

The results of the 2 methods show considerable differences (figs 1 and 2). Smallsized pollen grains (Cecropia sp. Piperaceae type 1, Myrtaceae type 1, Terminalia $\mathrm{sp)}$ dominate the pollen counts (fig 1). Here Cecropia sp is by far the most important pollen source and is fairly constant throughout the year (except for April and March). According to the pollen counts (fig 1), only a few plant species are important pollen sources and the variation in the pollen spectrum is very low.
Data for the volume estimates (fig 2), however, reveal a different pattern in the use of pollen sources by the honeybees. Cecropia sp and Palmae type 1 are equally important pollen sources. Cecropia sp is not a constantly dominating source as it was in the pollen counts, but has 2 periods of importance (July-October; DecemberFebruary) and is almost completely absent during the rest of the year.

Many other species that have relatively large pollen grains (eg Ceiba pentandra, Abutilon type, Cocos nucifera, Palmae sp) have much higher values in the volume es- 


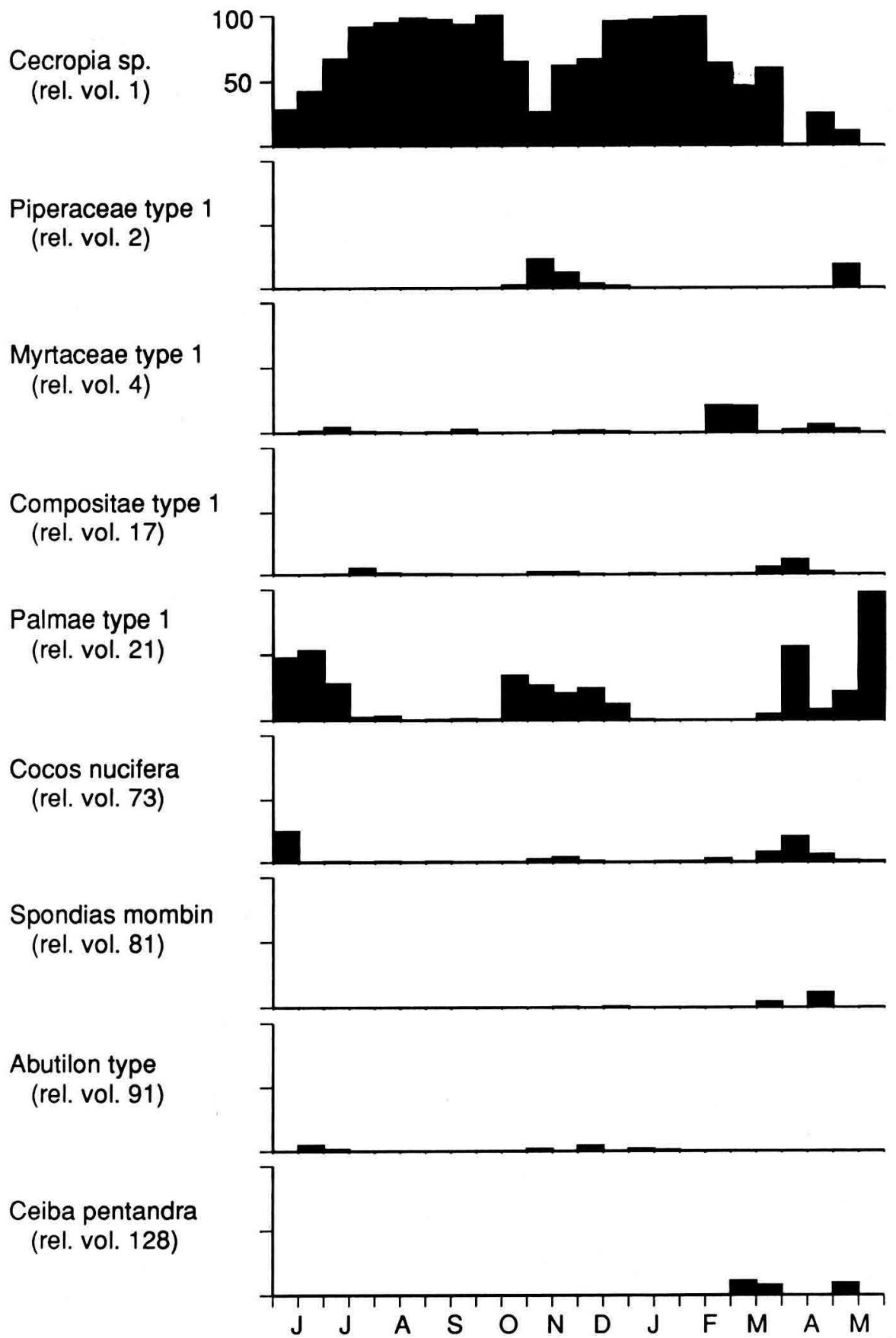

Fig 1. Representation of most important pollen types according to pollen grain counts. 


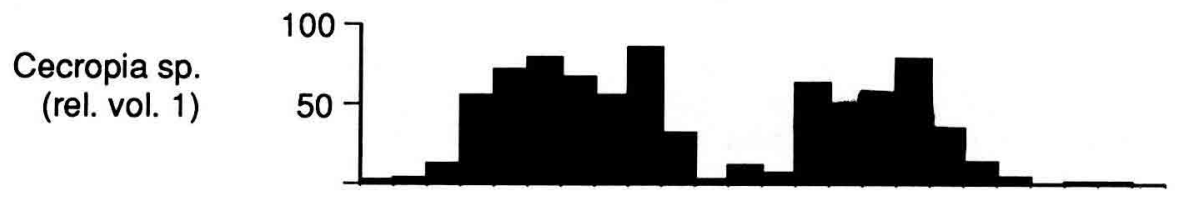

Piperaceae type 1 (rel. vol. 2)

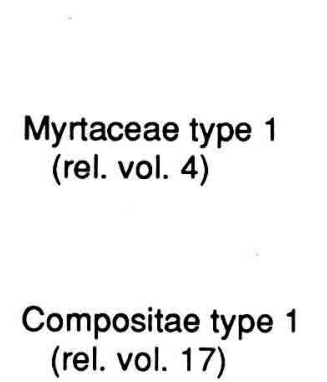

\section{Palmae type 1 \\ (rel. vol. 21)}

\section{Cocos nucifera \\ (rel. vol. 73)}

Abutilon type

Spondias mombin

(rel. vol. 81)

(rel. vol. 91)

Ceiba pentandra (rel. vol. 128)
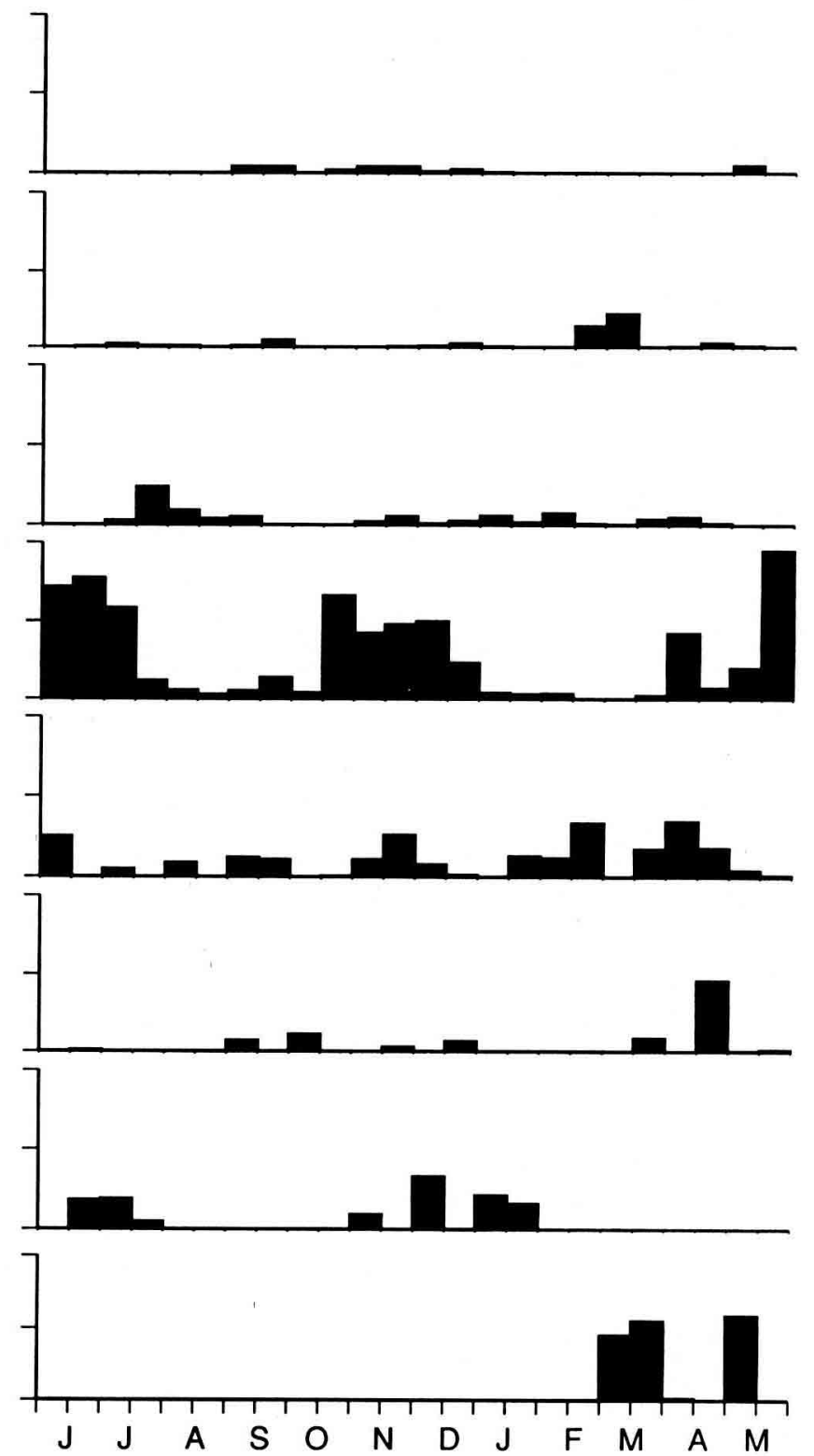

Fig 2. Representation of most important pollen types according to volume estimations. 
timates (fig 2), and should therefore be considered to be more important pollen sources than is suggested by the pollen grain counts (fig 1). In general, the variation in important pollen sources during a certain period is higher in the volume calculation method than with the pollen grain count method.

Monthly pollen niche size and evenness are given in figures 3 and 4 for both methods. Pollen counts for both niche size and evenness are highest in April and lowest in August, September and January. Pollen volume measurements, however, show a more regular pattern. Noteworthy is the fact that overall values for niche size as well as for evenness are somewhat higher with pollen volume measurements than with pollen counts.

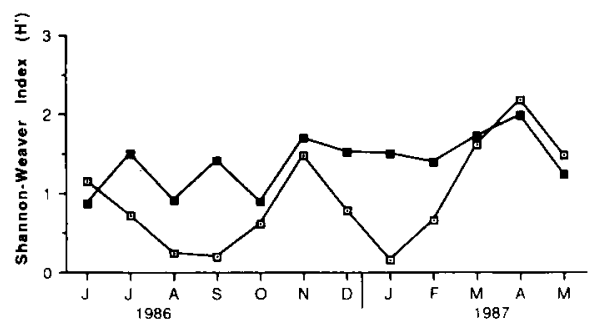

Fig 3. Pollen niche size of Apis mellifera in Surinam, using Shannon-Weaver diversity index (H') (1949). According to pollen counts ( $\square$ ) and pollen volume ( $\square$.

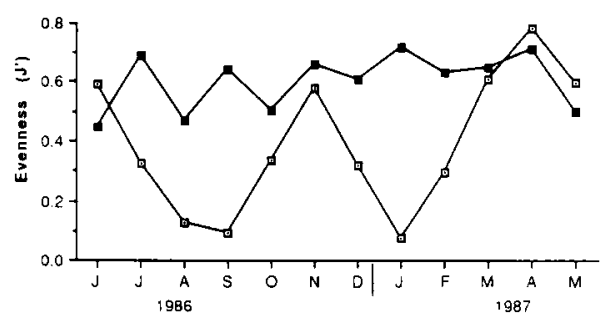

Fig 4. Evenness $\left(J^{\prime}\right)$ of pollen resource use by Apis mellifera in Surinam. According to pollen counts ( $\square$ ) and pollen volume ( $\square$ ).

\section{DISCUSSION}

\section{Spectrum of pollen sources}

Although the pollen spectrum of Apis mellifera observed in this study is the only record for Surinam, these data can be compared with other studies carried out in tropical America (table I). A considerable part of the flora of Surinam also occurs in the other Guianas (Guyana and French Guiana) and on Trinidad. Therefore the results obtained by Roubik (1979) (French Guiana), Sommeijer et al (1983) (Trinidad) seem to be the most suitable ones for comparison. Plant communities in other parts of tropical and subtropical America are very different, so studies from Panama (Roubik et al, 1986) and São Paulo, Brazil (Cortopassi-Laurino and Ramalho, 1988; Imperatriz-Fonseca et al, 1989) only show overlap at the genus and family level.

In this study Cecropia sp Palmae type 1 and Cocos nucifera were found to be the most important pollen sources for honeybees throughout the year in Surinam. These types are also major pollen sources in other countries (table I). Momordica charantia has been previously reported as a food source for honeybees in Trinidad as well as for stingless bees in Surinam. The hogplum, Spondias mombin, a major pollen source in Surinam, was also found to be important for honeybees (and other bees) in Trinidad. Ceiba pentandra, which was found to be of major importance in Surinam from March to mid-May, was not reported to be a pollen source of honeybees in the above-mentioned studies.

There is a considerable overlap ( 3 species, 5 genera, 23 families) in the pollen spectrum of stingless bees (Melipona and Trigona; Engel and Dingemans-Bakels, 1980) and honeybees in Surinam, but none of the plant taxa constitutes a major 
pollen source for both groups. Overlap at family-level does not imply that the 2 bee groups use the same species. However, because of the different methods utilized and the lack of information on plant species occurring at the localities involved, we cannot conclude that these bees do not share major pollen sources.

\section{Comparison of methods}

\section{The present study}

The differences in the results yielded by the 2 methods require careful study.

Up till now all studies on food sources of honeybees and stingless bees in the neotropics have used pollen grain counts to determine the importance of the sources. It is clear that for bees, the pollen volume is far more important than the number of grains. As mentioned above, this creates a problem for the investigator because the grains of the various types of pollen collected by the bees differ considerably in diameter, resulting in even larger variations in volume.

The pollen diet of honeybees in Surinam on a single day and during the year is more diverse according to volume estimates than it is according to pollen counts. Several plant species are important pollen sources in volume estimates, but are not revealed as such by pollen counts.

Calculations based solely on pollen counts are also misleading. As can be concluded from our results (figs 3,4 ), there is considerable difference in the monthly niche size and evenness, as revealed by the 2 methods. On average the graphs representing the relative volume data show higher values, indicating a higher diversity of plant species used as pollen sources and a more homogeneous use of pollen sources than one would conclude from pollen counts. The analysis, based on the relative volume data, does not give pronounced peaks for diversity and evenness during specific periods of the year. Analysis based exclusively on the pollen counts, however, indicates that such peaks do exist.

\section{Other studies}

It is clear that the shortcomings of the pollen count method have an impact on the evaluation of the results of other studies. The actual effect depends on the size ranges of the recorded pollen types. For honeybee foragers, Cortopassi-Laurino and Ramalho (1988) found pollen grains ranging in length from approximately 10$71 \mu \mathrm{m}$. They considered Eucalyptus spp, Cecropia sp and Mimosa veloziana to be among the most frequently-visited plant species. However, the published photographs indicate that the pollen grains of all 3 species are relatively small. Other studies also record important sources of pollen with small grains, for example: Cecropia sp (Sommeijer et al, 1983).

\section{CONCLUSION}

It is concluded that results of pollen grain counts alone cannot be presented and interpreted directly as patterns of pollen source utilization. Volume is a better measure, although a precise estimate can sometimes constitute a problem. It is also preferable to use relative volume data rather than pollen counts for calculating niche size, evenness, niche overlap and other parameters. 
NOTE

During the processing of this manuscript, an article on the influence of pollen grain volume was published by FA da Silveira (1991). Cecropia $\mathrm{sp}$ also happened to be the smallest grain found in the latter study. The present authors support the main conclusions reached in that article.

\section{ACKNOWLEDGMENTS}

We thank $\mathrm{H}$ Velthuis and 2 anonymous reviewers for making useful suggestions concerning the manuscript and S McNab for linguistic improvements.

Résumé - Les sources de pollen pour Apis mellifera $L$ au Surinam, estimées d'après le volume des grains de pollen. Les informations sur les sources de nourriture des abeilles dans les régions néotropicales sont très éparses (revue récente par Ramalho et al, 1990) et cette étude est la première sur ce sujet concernant le Surinam. Notre premier objectif était d'identifier les sources de pollen d'Apis mellifera et d'étudier leur variation au cours de l'année. Le second but était l'étude de l'importance relative des sources spécifiques de pollen. Jusqu'à présent, l'importance des sources de pollen était mesurée directement en comptant les grains de pollen*. II est clair, néanmoins, que pour les abeilles le volume des grains de pollen est beaucoup plus important que leur nombre. C'est pourquoi les comptages ne rendent pas compte de l'importance réelle de ces sources pour les abeilles. Nous avons mis au point une méthode d'estimation du volume relatif des grains de pollen afin de déterminer leur importance relative. Les résultats des 2 méthodes (comptage des grains et estimation du volume) ont été comparés.
Tous les 3 ou $4 \mathrm{j}$ pendant toute une année (mai 1986-mai 1987) des échantillons de pollen ont été prelevés dans 92 ruches d'A mellifera au Surinam et traités par une méthode standard d'acétolyse (Reitsma, 1969). Le volume a été estimé et le volume relatif calculé par rapport à celui des grains de pollen de Cecropia sp (le plus petit type de pollen trouvé). Chaque échantillon comprenait jusqu'à 15 types de pollen. Au total 52 types ont été trouvés, dont 21 étaient présents dans plus de $10 \%$ des échantillons (tableau I). D'après les estimations de volume relatif combinées à la fréquence, les sources de pollen les plus importantes tout au long de l'année sont: Cecropia sp, les Palmae type 1. Cocos nucifera et les Compositae type 1. Les types de pollen très épisodiques comprennent : Ceiba pentandra, les Myrtaceae type 1, le type Abutilon, Spondias mombin, Terminalia sp.

Les résultats des comptages et des estimations de volume présentent des différences considérables. Les données provenant des estimations de volume indiquent pour les abeilles un régime beaucoup plus diversifié que les comptages, aussi bien durant l'année qu'au cours d'une journée. Nous en concluons que les comptages de pollen ne peuvent pas être considérés comme reflet direct de l'utilisation des sources de pollen. Le volume est une mesure meilleure, bien que son estimation précise puisse poser des problèmes.

\footnotetext{
* Pendant la publication du présent article, un autre travail de FA de Silveira sur l'influence du volume des grains de pollen a donné lieu à une publication (1991). Les plus petits grains de pollen de cette étude furent aussi ceux d'une espèce de Cecropia. Les auteurs du présent article souscrivent aux principales conclusions de FA de Silveira.
} 
analyse pollinique / volume du grain de pollen / plante pollinifère / région néotropicale

\section{Zusammenfassung - Die Pollenquellen} für Apis mellifera L (Hym, Apidae) in Surinam, bestimmt durch Schätzung des Volumens der Pollenkörner. Informationen über die Nahrungsquellen der Bienen in den Neotropen sind sehr unvollständig (zum letzten Mal zusammengefaßt durch Ramalho, 1990) und dies ist die erste Untersuchung über Nahrungsquellen für Bienen in Surinam. Unser erstes Ziel war die Bestimmung der Pollenquellen von Apis mellifera und die Untersuchung der Variation dieser Quellen das Jahr über. Unser zweites Ziel bestand darin, die relative Bedeutung von bestimmten Pollenquellen zu untersuchen. Bisher wurde die Bedeutung der Pollenquellen direkt durch Zählung der Pollenquellen gemessen*. Es ist jedoch klar, daß für die Bienen das Volumen der Pollenkörner weit wichtiger ist als ihre Zahl. Deshalb geben diese Zahlen nicht die wirkliche Bedeutung dieser Quellen für die Bienen wieder. Wir entwickelten eine Methode zur Schätzung des relativen Volumens von Pollenkörnern, um ihre relative Bedeutung zu bestimmen. Die Resultate von den üblicherweise benutzten Pollenzählungen und unserer Methode der Schätzung des relativen Volumens wurden verglichen.

Alle drei Tage wurden über ein volles Jahr (Mai 1986-Mai 1987) von Völkern von Apis mellifera in Surinam Pollenproben entnommen (insgesamt 92) und nach einer Standard-Azetolysemethode behandelt (Reitsma, 1969). Das Volumen der Körner wurde geschätzt und das relative Volumen im Vergleich zu den Pollenkörnern von $\mathrm{Ce}$ cropia sp (dem kleinsten vorhandenen Pollentyp) berechnet. Jede Probe enthielt bis zu 15 Pollentypen. Insgesamt wurden 52
Pollentypen gefunden, von denen 21 in mehr als $10 \%$ der Proben auftraten (Tabelle I). Auf der Grundlage der relativen Volumenschätzungen in Kombination mit der Häufigkeit wurden als wichtigste Pollenquelle das ganze Jahr über Cecropia sp, Palmen-Typ 1, Cocos nucifera und Kompositen Typ 1 bestimmt. Pollenformen von großer Bedeutung zu bestimmten Perioden waren Ceiba pentandra, Myrtaceae Typ 1, Abutilon Typ, Spondias mombin, Terminalia sp.

Die Ergebnisse der Pollenzählungen und der Volumenschätzungen zeigten beträchtliche Unterschiede. Die Daten der Volumenschätzungen zeigen viel größere Unterschiede in der Bienennahrung über das Jahr wie auch über einen einzelnen Tag als die Pollenzählungen. Wir schließen daraus, daß die Ergebnisse der Pollenzählungen nicht unmittelbar als Muster der Nutzung von Pollenquellen dargestellt werden können. Das Volumen ist ein besseres Maß, obwohl seine Schätzung Probleme bieten kann.

* Inzwischen wurde ein Artikel von FA da Silveira veröffentlicht (1991). Wir bestätigen die wichtigsten Schluss-folgerungen.

\section{Pollenanalyse / Pollenvolumen / Schätz- verfahren / Pollenpflanze / Neotropen}

\section{REFERENCES}

Bootsma MC, Sommeijer MJ, Punt W (1988) Etude des ressources florales des Melipona trinitatis (Hymenoptera, Meliponinae) à quatre localités à Trinidad, Antilles. Actes Colloq Insectes Soc 4, 295-299

Cortopassi-Laurino M, Ramalho M (1988) Pollen harvest by Africanized Apis mellifera and Trigona spinipes in Sao Paulo: botanical and ecological views. Apidologie 19, 1-24 
Cruz-Landim C da (1985) Avaliação fotográfica da digestão do pólen presente no intestino de operárias de Apis mellifera L (Hymenoptera, Apidae). Naturalia 10, 27-36

Engel MS, Dingemans-Bakels SF (1980) Nectar and pollen resources for stingless bees (Meliponinae, Hymenoptera) in Surinam (South America). Apidologie 11, 341-350

Imperatriz-Fonseca VL, Kleinert-Giovannini $A$, Ramalho M (1989) Pollen harvest by eusocial bees in a non-natural community in Brazil. J Trop Ecol 5, 239-242

Kroon GH, Praagh JP van, Velthuis HHW (1974) Osmotic shock as a prerequisite to pollen digestion in the alimentary tract of the worker honeybee. J Apic Res 13, 177-181

Pielou EC (1977) Mathematical Ecology. John Wiley and Sons, New York, 2nd edn, 385 pp

Ramalho $M$, Imperatriz-Fonseca VL, KleinertGiovannini A, Cortopassi-Laurino M (1985) Exploitation of floral resources by Plebeia remota Holmberg (Apidae, Meliponinae). Apidologie 16, 307-330

Ramalho M, Kleinert-Giovannini A, ImperatrizFonseca VL (1990) Important bee plants for stingless bees (Melipona and Trigonini) and Africanized honeybees (Apis mellifera) in neotropical habitats: a review. Apidologie 21, 469-488

Reitsma T (1969) Size modifications of recent pollen under different treatments. Rev Paleobot Palynol 9, 175-202

Roubik DW (1979) Africanized honey bees, stingless bees, and the structure of plantpollinator communities. Proc IVth Symp Polli- nation. Md Agric Exp Stat Spec Misc Publ 1, 403-417

Roubik DW, Moreno JE, Vergara L, Wittmann D (1986) Sporadic food competition with the African honey bee: projected impact on neotropical social bees. J Trop Ecol 2, 97-111

Roubik DW, Moreno JE (1990) Social bees and palm trees: What do pollen diets tell us? In: Social Insects and the Environment (Veeresh GK, Mallik B, Viraktamath CA, eds) Proc 11 th Int Congr IUSSI, Oxford and IBH Publ Corp, New Delhi, India, 427-428

Seeley TD (1985) Honeybee Ecology. Princeton University Press, Princeton, $201 \mathrm{pp}$

Seeley TD, Camazine S, Sneyd J (1991) Collective decision-making in honey bees: how colonies choose among nectar sources. Behav Ecol Sociobiol 28, 277-290

Shannon CE, Weaver W (1949) The mathemati$\mathrm{cal}$ Theory of Communication. Univ of Illinois Press, Urbano, IL, $117 \mathrm{pp}$

Silveira FA da (1991) Influence of pollen grain volume on the estimation of the relative importance of its source to bees. Apidologie 22, 495-502

Sommeijer MJ, Rooy GA de, Punt W, Bruijn LLM de (1983) A comparative study of foraging behavior and pollen resources of various stingless bees (Hymenoptera, Meliponinae) and honeybee (Hymenoptera, Apinae) in Trinidad, West Indies. Apidologie 14, 205224

Stanley RG, Linskens HF (1974) Pollen: Biology Biochemistry Management. Springer-Verlag, Berlin, $307 \mathrm{pp}$ 